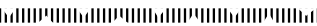

巻 頭 言

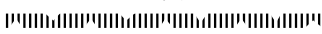

\title{
RHEED に対する雑感
}

堀尾吉 已

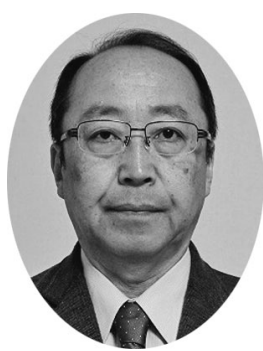

電子は今から 120 年前に発見され，その波動性は 90 年前に実証された。意外やその僅か 1 年後の 1928 年には西川と菊池により方解石を用いた先駆的 RHEED 実験が行われている。そ の意味で日本の RHEED の歴史は長く，数多くの成果を残した。たとえば三宅によるエピタキ シャル成長観察や上田の “その場” 薄膜成長観察，そして超高真空技術が広く普及する 1970 年代になると井野による $\mathrm{Si}(111) 7 \times 7$ 表面の見事な RHEED パターンが発表され，多くの研究 者を魅了した。また，一宮による RHEED 強度の動力学的理論は表面構造の解析に広く利用さ れた。

“百聞は一見にしかず”の諺があるように実空間観察法である STM が 1983 年に開発され， 高柳らの歴史的な $\mathrm{Si}(111) 7 \times 7$ 表面の DAS 構造モデルの検証にも貢献している。STM 像は直 感的に理解しやすいが，その像解釈は単純でないため，現在も反射回折法は表面構造解析の有 力な手法の一つとなっている。その後, 非弾性散乱成分除去のためのエネルギーフィルター型 RHEED の開発や，ワイゼンベルグ RHEED 法のように入射方位を細かく変化させて撮影した 膨大な数の回折図形の画像処理とフーリエ変換から直接的に表面構造を導き出す手法も開発さ れた。また，電子の代わりに陽電子を用い，特に最表面の構造解析に有効な陽電子回折の研究 も進展している。このようにRHEED 関連分野は，まだ進化の過程にあるように思われる。

視点を変えて眺めると，これまでの反射回折法は表面で反射回折し，真空中に出射する電子 が形成する回折図形に注目している。一方，結晶表面内部に侵入する入射電子波が形成する電 子密度分布すなわち波動場にはほとんど注目されてこなかった。今後の展望として，入射条件 変化により結晶表面内部にどのような波動場が形成されるかといった基礎的研究が望まれる。 多重散乱する電子の回折強度，たとえば RHEED のロッキング曲線や LEED の I-V 曲線を見て もわかるように運動学的考察では解釈できない複雑なピークが現れる。その起源を解明する上 で結晶内波動場は重要であろう。また，入射電子波動場の密と疎の場所が原子列とどのような 位置関係にあり，特性 X 線やオージェ電子の励起とどのような相関性があるかを明らかにす ることは新たな分析手法の開発に役立つであろう。さらに，周期的に原子列を電子励起する際 にも波動場の描像を理解することは重要であろう。

早いもので還暦を過ぎ，星の輝く時刻に起床することが増えた。特に冬期には濃紺色の天空 が暁，東雲を迎えるころになると，地平線からオレンジ色の何とも鮮やかなグラデーションが 現れる。そして曙，朝朗を経て太陽が昇り天空は色を変えて明るくなる。この光景は RHEED 観察において，入射電子をきわめて低い視射角から高くしていくときのパターン変化に感覚的 に重なるものがあり，何故か私にトキメキを感じさせてくれる。

(大同大学) 